\title{
PERBEDAAN PENGARUH LAMA PEMAKAIAN KONTRASEPSI PIL KOMBINASI DENGANDMPA TERHADAP PENINGKATAN INDEKS MASSA TUBUH
}

\author{
Endah Kamila Mas'udah*, Moh.Wildan**, Dina Fristy Dzulhijjah*** \\ ${ }^{1,2,3}$ Poltekkes Kemenkes Malang. Jl. Besar Ijen No.77C, Oro-oro Dowo, Kec. Klojen, Kota Malang, \\ Jawa Timur 65119 Indonesia \\ Email : kamilaendah@gmail.com
}

\begin{abstract}
ABSTRAK
Kontrasepsi hormonal jangka pendek menjadi alat kontrasepsi yang paling banyak diminati wanita usia subur karena bersifat efektif dan reversibel untuk mencegah terjadinya kehamilan. Kontrasepsi oral kombinasi bekerja secara primer dengan cara menghambat ovulasi. Sedangkan kontrasepsi suntik DMPA menekan pembentukan releasing faktor dan hipotalamus untuk menghambat penetrasi sperma melalui serviks uteri. Salah satu efek samping penggunaan kontrasepsi hormonal adalah peningkatan berat badan yang dapat mempengaruhi nilai IMT. Tujuan penelitian adalah mengetahui perbedaan pengaruh lama pemakaian kontrasepsi pil kombinasi dengan DMPA terhadap peningkatan IMT. Metode penelitian menggunakan retrospektif komparatif observasional dengan rancangan penelitian cross sectional. Teknik sampling menggunakan Purposive Sampling dengan Besar sampel pil kombinasi sebanyak 15 orang dan 23 orang akseptor KB suntik DMPA. Intrumen penelitian menggunakan kuesioner akseptor KB. Hasil uji Chi-Square didapatkan $\rho$ value pil kombinasi $(0,001)<$ $\alpha$ dan suntik DMPA $(0,048)<\alpha$. Kesimpulan secara statistik H0 ditolak yang artinya ada pengaruh, pil kombinasi memiliki hubungan yang lebih erat terhadap lama pemakaian kontrasepsi dengan peningkatan indeks masa tubuh dibandingkan suntik DMPA. Kandungan hormon estrogen dan progesteron dalam pil kombinasi bekerja secara aktif dalam menstimulasi lemak tubuh sementara kandungan progesteron saja dalam suntik DMPA meningkatkan kadar LDL yang menyebabkan pil kombinasi lebih besar pengaruhnya dalam peningkatan IMT dibanding DMPA. Oleh karena itu, diharapkan petugas kesehatan dapat memantau IMT akseptor selama pemakaian kontrasepsi untuk mencegah angka kejadian obesitas.
\end{abstract}

\section{Kata Kunci : Pil kombinasi, suntik DMPA, Indeks Massa Tubuh (IMT)}

\section{ABSTRACK}

The short-term hormonal contraception is the most popular contraceptive method for women childbearing age because it is effective and reversible to prevent pregnancy. Combined oral contraceptives work primarily by inhibiting ovulation. Whereas DMPA injection contraception suppresses the formation of releasing factors and the hypothalamus to inhibit sperm penetration through the cervix uteri. One side effect of using hormonal contraception is an increase in body weight which can affect the value of BMI. The aim of the study was to determine the differences in the effect of the duration of use of combined pill with DMPA on increasing BMI. The research method uses an observational comparative retrospective with a cross sectional study design. The sampling technique uses purposive sampling with 15 combination pill samples and 23 DMPA injection acceptor acceptors. The research instrument used the KB acceptor questionnaire. Chi-Square test results obtained $\rho$ value of combined pills (0.001) $<\alpha$ and DMPA injections (0.048) $<\alpha$. The statistical conclusion of HO is rejected which means that there is an effect, the combination pill has a closer relationship with the duration of contraceptive use with an increase in body mass index than the DMPA injection. The content of the hormones estrogen and progesterone in combination pills works actively in stimulating body fat while the content of progesterone alone in DMPA injections increases LDL levels which causes the combination pill to have a greater effect on increasing BMI than DMPA. Therefore, it is expected that health workers can monitor BMI acceptors during contraceptive use to prevent the incidence of obesity.

Keywords: Combination pills, DMPA injections, Body Mass Index (BMI. 


\section{PENDAHULUAN}

Program Keluarga Berencana (KB) merupakan bagian upaya penanggulangan ledakan penduduk dunia umumnya dan punduduk Indonesia khususnya. Pemerintah dalam menekan ledakan penduduk melalui program $\mathrm{KB}$ bertujuan untuk melembagakan "Keluarga Berkualitas" melalui pengaturan kehamilan dan kelahiran anak dengan mempertimbangkan jarak dan usia ideal melahirkan (BKKBN, 2010).

Fenomena di masyarakat saat ini banyak wanita usia subur yang memilih menggunakan kontrasepsi hormonal. Kontrasepsi hormonal diyakini lebih bersifat praktis, efektif, dan tidak perlu khawatir adanya benda asing yang dimasukkan ke dalam tubuh akseptor seperti spiral maupun susuk.

Berdasarkan laporan Badan Kependudukan dan Keluarga Berencana Nasional (BKKBN) dan Pemberdayaan Masyarakat Kota Malang, jumlah akseptor kontrasepsi terbanyak di kota Malang adalah akseptor KB Pil sebanyak dan akseptor suntik hormonal sebanyak $68,2 \%$ (Kemenkes RI, 2018). Dinas Penduduk dan Keluarga Berencana Kabupaten Malang (2016), kecamatan yang memiliki jumlah akseptor KB pil kombinasi dan suntik DMPA terbanyak berada di kecamatan DAU dengan proporsi akseptor pil kombinasi sebanyak 4.422 orang dan akseptor suntik DMPA sebanyak 4.490 orang (Kemenkes RI, 2013).

Setiap kontrasepsi tentu mempunyai efek samping, salah satu efek samping kontrasepsi hormonal adalah peningkatan berat badan (Manuaba, 2010). Secara teoritis, mekanisme biologis kenaikan berat badan sehubungan dengan pengaruh hormon estrogen dan progesteron yang terkandung dalam kontrasepsi kombinasi disebabkan oleh retensi cairan secara sekunder karena aktivasi mineralokortikoid atau renin-angiotensin-aldosteron dan terjadinya peningkatan lemak subkutan secara sekunder karena secara hormonal menyebabkan peningkatan nafsu makan dan asupan makanan (Samosir, 2013).

Penggunaan progesteron saja dalam kontrasepsi suntik DMPA menyebabkan kadar estrogen menjadi berkurang. Salah satu fungsi estrogen antagonis terhadap progesteron berkaitan dengan metabolisme lemak, dimana estrogen berfungsi untuk meningkatkan kadar High-density Lipoprotein (HDL) dan alpha lipoprotein yaitu lemak yang dapat larut dalam air. Sedangkan, progesteron menurunkan kadar HDL dan meningkatkan Low-density Lipoprotein (LDL) yang bersifat tidak larut dalam air sehingga apabila asupan makanan yang mengandung banyak lemak terus dikonsumsi maka LDL akan banyak tertimbun dan tersimpan dalam tubuh. 
Lemak yang tersimpan ditubuh akan mengakibatkan kenaikan berat badan sehingga mempengaruhi Indeks Masa Tubuh (IMT) seseorang (Supariasa, 2002).

Penelitian Andriyati, dkk (2014) menunjukkan bahwa kontrasepsi hormonal oral kombinasi yang mengandung hormon estrogen dan progesteron menyebabkan kenaikan berat badan. Penelitian Setyarini (2015) menunjukkan bahwa kontrasepsi suntik DMPA secara signifikan dalam jangka lama menyebabkan peningktan kadar lemak tubuh dan IMT.

Sebagai tenaga kesehatan yang dekat dengan masyarakat khususnya wanita, bidan perlu memperhatikan status gizi akseptor. Karena selama siklus hidupnya wanita akan melewati proses menstruasi, hamil, melahirkan, menyusui dan menjadi prioritas utama dalam pengunaan kontrasepsi. Apabila penggunaan kontrasepsi oleh akseptor tidak diikuti pemantauan oleh petugas kesehatan, akan menimbulkan efek samping meningkatnya berat badan dan timbulnya penyakit degeneratif yang dapat merugikan wanita.

\section{METODE PENELITIAN}

Penelitian ini merupakan penelitian retrospektif komparatif observasional dengan desain penelitian menggunakan pendekatan cross sectional. Populasi penelitian ini adalah seluruh akseptor KB pil kombinasi dan suntik DMPA dengan lama pemakaian 12 bulan pada bulan Mei 2019. Besar sample dalam penelitian ini didapatkan hasil jumlah sampel akseptor pil kombinasi 15 orang dan sampel akseptor KB suntik DMPA sebanyak 23 orang yang memenuhi kriteria inklusi. Teknik pengambilan sampel menggunakan Nonprobability Sampling dengan Purposive Sampling. Pelaksanaan penelitian dilaksanakan mulai tanggal 01 Mei - 17 Mei 2019.

Instrumen pengumpulan data dalam penelitian ini dilakukan dengan menggunakan pengukuran langsung kepada responden. Penilaian lama pemakaian menggunakan kuesioner akseptor keluarga berencana. Peningkatan berat badan dan IMT diukur menggunakan lembar observasi dengan alat ukur timbangan digital dan stature meter. Uji statistik yang digunakan adalah uji chisquare.

\section{HASIL DAN PEMBAHASAN}

Penelitian dilakukan pada tanggal 01 Mei 2019 sampai 17 Mei 2019. Subyek pada penelitian ini sebanyak 15 orang akseptor pil kombinasi dan 23 orang akseptor suntik DMPA di PMB Dwi Astutik, A.Md, Keb Dau Kabupaten Malang. Adapaun hasil dari peneltian terdapat karakteristik akseptro dan lama pemakaian kontrasepsi pil kombinasi dan suntik DMPA. Hasil penelitian ini disajikan 
dalam bentuk tabel distribusi frekuensi.

Data yang telah terkumpul diolah dan diinterprestasikan sehingga mengahasilkan suatu analisis sebagai berikut:

\section{Data Umum}

a. Karakteristik Responden Berdasarkan Umur

Tabel 4.1 Distribusi Frekuensi Responden Akseptor Pil Kombinasi di PMB Dwi Astutik, A.Md, Keb Dau Kabupaten Malang pada bulan Mei 2019

\begin{tabular}{ccc}
\hline Usia & $\boldsymbol{f}$ & $\mathbf{\%}$ \\
\hline$<20$ tahun & 1 & 6,7 \\
$20-35$ tahun & 9 & 60 \\
$>35$ tahun & 5 & 33,3 \\
\hline Jumlah & $\mathbf{1 5}$ & $\mathbf{1 0 0}$ \\
\hline
\end{tabular}

Tabel 4.2 Distribusi Frekuensi Responden Akseptor Suntik DMPA di PMB Dwi Astutik, A.Md, Keb Dau Kabupaten Malang pada bulan Mei 2019

\begin{tabular}{ccc}
\hline Usia & $\boldsymbol{f}$ & $\mathbf{\%}$ \\
\hline$<20$ tahun & 1 & 4,3 \\
20-35 tahun & 15 & 65,2 \\
$>35$ tahun & 7 & 30,4 \\
\hline Jumlah & $\mathbf{2 3}$ & $\mathbf{1 0 0}$ \\
\hline
\end{tabular}

Berdasarkan Tabel 4.1 dan Tabel 4.2 mayoritas responden akseptor pil kombinasi $(60,0 \%)$ dan suntik DMPA $(65,2 \%)$ berusia $20-35$ tahun.

Penambahan berat badan pada usia muda lebih cepat terjadi dari pada orang tua. Hal ini dikarenakan pola aktifitas dan pola makan seseorang yang berpengaruh terhadap metabolisme lemak dalam tubuh. Penumpukkan simpanan lemak dalam tubuh akan menyebabakn peningkatan berat badan (Suparyanto, 2010). Orang yang sudah lanjut usia membutuhkan waktu yang lebih banyak dalam memetabolisme lemak tubuh, sehingga penumpukkan simpanan lemak cenderung mudah terjadi pada usia muda bila tidak diimbangi dengan aktivitas yang sesuai dengan masukkan sejumlah kalori dalam tubuh.

b. Karakteristik Responden Berdasarkan Paritas

Tabel 4.3 Distribusi Frekuensi Responden Akseptor Pil Kombinasi di PMB Dwi Astutik, A.Md, Keb Dau Kabupaten Malang pada bulan Mei 2019

\begin{tabular}{ccc}
\hline Paritas & $\boldsymbol{f}$ & $\mathbf{\%}$ \\
\hline Primipara & 7 & 46,7 \\
Multipara & 5 & 33,3 \\
Grandemultipara & 3 & 20 \\
\hline Jumlah & $\mathbf{1 5}$ & $\mathbf{1 0 0}$ \\
\hline
\end{tabular}

Tabel 4.4 Distribusi Frekuensi Responden Akseptor Suntik DMPA di PMB Dwi Astutik, A.Md, Keb Dau Kabupaten Malang pada bulan Mei 2019

\begin{tabular}{ccc}
\hline Paritas & $\boldsymbol{f}$ & $\boldsymbol{\%}$ \\
\hline Primipara & 10 & 43,5 \\
Multipara & 10 & 43,5 \\
Grandemultipara & 3 & 13,0 \\
\hline Jumlah & $\mathbf{2 3}$ & $\mathbf{1 0 0}$ \\
\hline
\end{tabular}

Berdasarkan tabel 4.3 dan 4.4 diatas dapat diketahui bahwa paritas sebagian besar responden pil kombinasi $(46,7 \%)$ dan suntik DMPA $(43,5 \%)$ adalah primipara dan multipara.

Mayoritas responden adalah primipara, hal ini menunjukkan bahwa 
penggunaan kontrasepsi pada fase menjarangkan dimaksudkan untuk menunda kehamilan atau menjaga jarak kehamilan berikutnya

c. Karakteristik Responden Berdasarkan Pendidikan

Tabel 4.5 Distribusi Frekuensi Responden Akseptor Pil Kombinasi di PMB Dwi Astutik, A.Md, Keb Dau Kabupaten Malang pada bulan Mei 2019

\begin{tabular}{ccc}
\hline Pendidikan & $\boldsymbol{f}$ & $\mathbf{\%}$ \\
\hline SD & 5 & 33,3 \\
SMP & 4 & 26,7 \\
SMA & 5 & 33,3 \\
Perguruan & 1 & 6,7 \\
Tinggi (PT) & & \\
\hline Jumlah & $\mathbf{1 5}$ & $\mathbf{1 0 0}$ \\
\hline
\end{tabular}

Tabel 4.6 Distribusi Frekuensi Responden Akseptor Suntik DMPA di PMB Dwi Astutik, A.Md, Keb Dau Kabupaten Malang pada bulan Mei 2019.

\begin{tabular}{ccc}
\hline Pendidikan & $\boldsymbol{f}$ & $\mathbf{\%}$ \\
\hline SD & 13 & 56,5 \\
SMP & 4 & 17,4 \\
SMA & 4 & 17,4 \\
Perguruan & 2 & 8,7 \\
Tinggi (PT) & & \\
\hline Jumlah & $\mathbf{2 3}$ & $\mathbf{1 0 0}$
\end{tabular}

Berdasarkan tabel 4.5 dan 4.6 diatas dapat diketahui bahwa pendidikan terakhir sebagian besar responden akseptor pil kombinasi $(33,3 \%)$ dan akseptor suntik DMPA $(56,5 \%)$ berada pada jenjang SD dan SMA.

Hasil penelitian ini menunjukkan bahwa sebagian besar responden masih belum paham dan mengerti mengenai efek samping yang ditimbulkan selama pemakaian kontrasepsi pil kombinasi dan suntik DMPA yang mana kedua jenis kontrasepsi ini merupakan kontrasepsi jenis hormonal yang mudah mempengaruhi nafsu makan seseorang dan mempercepat metabolisme lemak dalam tubuh. Sebelum pemberian kontrasepsi petugas kesehatan telah menyampaikan efek samping yang diitimbulkan, akan tetapi masih banyak responden yang belum memahaminya sehingga tingkat pendidikan seseorang sangat menentukan seberapa besar pemahaman akseptor dalam menangkap informasi yang dberikan secara tepat dan cepat.

d. Karakteristik Responden Berdasarkan Pekerjaan

Tabel 4.7 Distribusi Frekuensi Responden Akseptor Pil Kombinasi di PMB Dwi Astutik, A.Md, Keb Dau Kabupaten Malang pada bulan Mei 2019.

\begin{tabular}{ccc}
\hline Pekerjaan & $\boldsymbol{f}$ & $\mathbf{\%}$ \\
\hline Wiraswasta & 2 & 13,3 \\
Swasta & 3 & 20 \\
IRT & 7 & 46,7 \\
Lainnya & 3 & 20 \\
\hline Jumlah & $\mathbf{1 5}$ & $\mathbf{1 0 0}$ \\
\hline
\end{tabular}

Tabel 4.8 Distribusi Frekuensi Responden Akseptor Suntik DMPA di PMB Dwi Astutik, A.Md, Keb Dau Kabupaten Malang pada bulan Mei 2019

\begin{tabular}{ccc}
\hline Pekerjaan & $\boldsymbol{f}$ & $\mathbf{\%}$ \\
\hline Wiraswasta & 2 & 8,7 \\
Swasta & 4 & 17,4 \\
IRT & 13 & 56,5 \\
Lainnya & 4 & 17,4 \\
\hline Jumlah & $\mathbf{2 3}$ & $\mathbf{1 0 0}$ \\
\hline
\end{tabular}


Berdasarkan tabel 4.7 dan 4.8 diatas dapat diketahui bahwa sebagian besar responden akseptor pil kombinasi $(46,7 \%)$ dan suntik DMPA $(56,5 \%)$ sebagian besar adalah ibu rumah tangga.

Berdasarkan data tersebut memberi gambaran bahwa status pekerjaan responden berpengaruh terhadap tingkat aktivitas responden. Rata-rata ibu yang tidak bekerja ketika sudah di rumah enggan untuk beraktivitas sehingga nafsu makan yang meningkat menyebabkan jumlah masukkan kalori dalam tubuh meningkat dan tidak dapat diubah secara sempurna menjadi energi. Penumpukkan kalori akan dimetabolisme tubuh menjadi lemak yang akan mempengaruhi berat badan seseorang.

\section{Data Khusus}

a. Akseptor Pil Kombinasi

\begin{tabular}{|c|c|}
\hline Tabel 4.9 & $\begin{array}{l}\text { Distribusi } \text { Frekuensi Lama } \\
\text { Pemakaian } \\
\text { Kontrasepsi Pil kombinasi di } \\
\text { PMB Dwi Astutik, A.Md, Keb } \\
\text { Dau Kabupaten Malang pada } \\
\text { bulan Mei 2019 }\end{array}$ \\
\hline Lama Pemakaian & Pemakaian \\
\hline & 2 bulan \\
\hline & 2 bulan \\
\hline \multicolumn{2}{|c|}{ Jumlah } \\
\hline
\end{tabular}

Tabel 4.10Distribusi Frekuensi Peningkatan IMT Akseptor Kontrasepsi Pil kombinasi setelah pemakaian kontrasepsi di PMB Dwi Astutik, A.Md, Keb Dau Kabupaten Malang pada bulan Mei 2019

\begin{tabular}{ccc}
\hline Peningkatan IMT & $\boldsymbol{f}$ & $\mathbf{\%}$ \\
\hline Naik & 10 & 66,7 \\
Turun & 5 & 33,3 \\
\hline Jumlah & $\mathbf{1 5}$ & $\mathbf{1 0 0}$ \\
\hline
\end{tabular}

Tabel 4.11 Tabulasi Silang Pengaruh Lama Pemakaian Pil Kombinasi dengan Peningkatan Indeks Massa Tubuh.

\begin{tabular}{ccccccc}
\hline $\begin{array}{c}\text { Lama } \\
\text { Pemakai } \\
\text { an }\end{array}$ & \multicolumn{2}{c}{ Peningkatan IMT } & \multicolumn{2}{c}{ Naik } & \multicolumn{2}{c}{$\begin{array}{c}\text { Tetap/ } \\
\text { Turun }\end{array}$} \\
\cline { 2 - 6 } & \multicolumn{4}{c}{ Total } \\
\cline { 2 - 6 } & $f$ & $\%$ & $f$ & $\%$ & $f$ & $\%$ \\
\hline 12 bulan & 9 & $(90)$ & 1 & $(10)$ & 10 & $(100)$ \\
\hline$>12$ bulan & 1 & $(20)$ & 4 & $(80)$ & 5 & $(100)$ \\
\hline Jumlah & $\mathbf{1 0}$ & $(\mathbf{6 6 , 7 )}$ & $\mathbf{5}$ & $\mathbf{( 3 3 , 3 )}$ & $\mathbf{1 5}$ & $(100)$ \\
\hline
\end{tabular}

Berdasarkan tabel 4.11 diatas dapat diketahui bahwa sebagian besar responden lama pemakaian kontrasepsi pil kombinasi selama 12 bulan. Rata-rata responden dalam penelitian ini mengalami kenaikan IMT pada 12 bulan pertama (90\%) dan IMT cenderung tetap atau menurun (80\%) pada lama pemakaian $>12$ bulan.

b. Akseptor Pil Kombinasi

Tabel 4.12 Distribusi Frekuensi Lama Pemakaian Akseptor Kontrasepsi suntik DMPA di PMB Dwi Astutik, A.Md, Keb Dau Kabupaten Malang pada bulan Mei 2019

\begin{tabular}{ccc}
\hline Lama Pemakaian & $\boldsymbol{f}$ & $\mathbf{\%}$ \\
\hline 12 bulan & 15 & 65,2 \\
$>12$ bulan & 8 & 34,8 \\
\hline Jumlah & $\mathbf{2 3}$ & $\mathbf{1 0 0}$ \\
\hline
\end{tabular}

Tabel 4.13Distribusi Frekuensi Peningkatan IMT Akseptor suntik DMPA setelah pemakaian kontrasepsi di PMB Dwi Astutik, A.Md, Keb Dau Kabupaten Malang pada bulan Mei 2019 


\begin{tabular}{|c|c|c|c|c|c|c|c|c|c|c|}
\hline \multirow{3}{*}{ Peningkatan IMT } & \multirow[b]{2}{*}{$f$} & & \multirow[b]{2}{*}{12 bulan } & \multirow[b]{2}{*}{15} & \multirow[b]{2}{*}{100} & \multirow[b]{2}{*}{0} & \multirow[b]{2}{*}{0} & \multirow[b]{2}{*}{15} & \multirow[b]{2}{*}{100} & \multirow{4}{*}{0,048} \\
\hline & & $\%$ & & & & & & & & \\
\hline & 22 & 95,7 & $>12$ bulan & 7 & 87 & 1 & 12 & 8 & 100 & \\
\hline Turun & 1 & 4,3 & & & 5 & & 5 & & & \\
\hline Jumlah & 23 & 100 & Hasil uji chi-squ & are $\mathrm{m}$ & enggu & $\mathrm{ka}$ & n fish & exa & t test & \\
\hline
\end{tabular}

Tabel 4.14 Tabulasi Silang Pengaruh

Lama Pemakaian suntik DMPA dengan Peningkatan Indeks Massa Tubuh.

\begin{tabular}{ccccccc}
\hline $\begin{array}{c}\text { Lama } \\
\text { Pemakai } \\
\text { an }\end{array}$ & \multicolumn{2}{c}{ Peningkatan IMT } & \multicolumn{2}{c}{ Naik } & \multicolumn{2}{c}{$\begin{array}{c}\text { Tetap/ } \\
\text { Turun }\end{array}$} \\
\cline { 2 - 6 } & & \multicolumn{4}{c}{ Total } \\
\cline { 2 - 6 } & $f$ & $\%$ & $f$ & $\%$ & $f$ & $\%$ \\
\hline 12 bulan & 15 & $(100)$ & 0 & $(0)$ & 15 & $(100)$ \\
\hline$>12$ bulan & 7 & $(87,5)$ & 1 & $(12,5)$ & 8 & $(100)$ \\
\hline Jumlah & $\mathbf{2 2}$ & $\mathbf{( 9 5 , 7 )}$ & $\mathbf{1}$ & $\mathbf{( 4 , 3 )}$ & $\mathbf{2 3}$ & $(100)$ \\
\hline
\end{tabular}

Berdasarkan tabel 4.14 diatas dapat diketahui bahwa sebagian besar responden lama pemakaian kontrasepsi suntik DMPA selama 12 bulan. Rata-rata responden dalam penelitian ini mengalami kenaikan IMT pada 12 bulan pertama sebesar (100 $\%)$ dan $(87,5 \%)$ pada lama pemakaian $>12$ bulan IMT tetap mengalami kenaikkan.

\section{c. Perbedaan Pengaaruh Lama Pemakaian terhadap peningkatan indeks massa tubuh}

Tabel 4.15Perbedaan Pengaruh Lama Pemakaian Pil Kombinasi dengan DMPA terhadap Peningkatan Indeks Massa Tubuh

\begin{tabular}{cccccccc}
\hline $\begin{array}{c}\text { Lama } \\
\text { Pemakaian } \\
\begin{array}{c}\text { Pil } \\
\text { Kombinasi }\end{array}\end{array}$ & \multicolumn{2}{c}{ Peningkatan IMT } & Total & P \\
\cline { 2 - 7 } & Naik & \multicolumn{5}{c}{$\begin{array}{c}\text { Tetap/ } \\
\text { Turun }\end{array}$} \\
\hline 12 bulan & 9 & 90 & 1 & 10 & 10 & 100 & \multirow{2}{*}{0,001} \\
\hline$>12$ bulan & 1 & 20 & 4 & 80 & 5 & 100 & \\
\hline
\end{tabular}

Lama Pemakaian Suntik DMPA

\section{Perbedaan Pengaruh Lama

Pemakaian Kontrasepsi Pil

Kombinasi dengan DMPA terhadap

Peningkatan Indeks Massa Tubuh

Hasil uji chi-square menggunakan analisa fisher exact test didapatkan nilai $\rho$ value pil kombinasi $0,001<\alpha$ dan $\rho$ value suntik DMPA 0,048< $<$, kesimpulan H0 ditolak yang artinya ada pengaruh. Jika kedua nilai $\rho$ value pil kombinasi dan suntik DMPA dibandingkan nilai $\rho$ value 0,048 > 0,001, secara statistik pil kombinasi memiliki hubungan yang lebih erat terhadap lama pemakaian kontrasepsi dengan peningkatan indeks massa tubuh dibandingkan dengan suntik DMPA di PMB Dwi Astutik Amd.Keb Kecamatan Dau Kabupaten Malang.

Penelitian yang dilakukan pada 15 responden akseptor pil kombinasi, menunjukkan bahwa setelah pemakaian kontrasepsi selama 12 bulan 9 orang (90\%) mengalami kenaikan IMT, 1 orang $(10 \%)$ IMT menetap dan selama pemakaian $>12$ bulan 1 orang $(20 \%)$ mengalami kenaikan IMT dan 4 orang (80\%) IMT menetap, sementara penelitian yang dilkukan pada 23 responden akseptor suntik DMPA selama 12 bulan 15 orang (100\%) mengalami 
peningkatan nilai IMT dan 7 orang $(87,5 \%)$ mengalami kenaikan IMT setelah pemakaian $>12$ bulan, dan 1 orang $(12,5 \%)$ nilai IMT menetap.

Lama pemakaian kontrasepsi pil kombinasi dan suntik DMPA diperhitugkan melalui tanggal pertama menjadi akseptor kemudian dihitung lama penggunaan hingga waktu penelitian. Lama penggunaan dihitung dari data register PMB Dwi Astutik A. Md. Keb. Dalam penelitian sebagian besar akseptor telah menggunakan kontrasepsi selama $\geq 12$ bulan. Rasa nyaman dan penggunaan kontrasepsi pil kombinasi maupun suntik DMPA yang dianggap praktis dan ekonomis menyebabkan akseptor tidak mau menggunakan alat kontrasepsi lainnya karena dianggap menakutkan misalnya IUD dan implan. Menurut Setyarini (2015) Ketakutan terhadap efek samping alat kontrasepsi tertentu cenderung menyebabkan akseptor lebih memilih satu kontrasepsi yang dianggap nyaman dan tidak memberi jeda untuk menggunakan kontrasepsi lain.

Penggunaan alat kontrasepsi hormonal dalam jangka lama memberikan efek samping pada hormon estrogen dan progesteron dalam tubuh. Ketidakseimbangan hormon dapat memicu perubahan pola haid, peningkatan risiko gangguan sirkulasi seperti, hipertensi, penyakit arteri dan tromboembolisme vena, peningkatan berat badan, dan peningkatan nafsu makan (Affandi, dkk., 2011). Setiap indivdu tidak selalu mengalami efek samping yang ditimbulkan, hal tersebut terjadi karena masing-masing individu memiliki adaptasi tersendiri terhadap pemberian hormon estrogen maupun progesteron.

Menurut Cook (2004) hormon estrogen dan progesteron dalam kontrasepsi pil kombinasi secara tidak langsung dapat memodulasi selera makan, penggunaan energi, dan metaboisme dalam tubuh. Hal ini dikarenakan jaringan adiposit (lemak) sangat responsif terhadap rangsangan estrogen sehingga nafsu makan yang meningkat menyebabkan deposisi lemak subkutam.

Penggunaan hormon progesteron saja dalam jangka waktu lama pada pemakaian kontrasepsi suntik DMPA menyebabkan kadar estrogen menjadi berkurang, fungsi estrogen yang bersifat antagonis terhadap progesteron dalam memetabolisme lemak menjadikan progesteron menurunkan kadar HDL (lemak yang larut dalam air) dan meningkatkan LDL (bersifat tidak larut air). Apabila asupan makanan yang mengandung banyak lemak terus dikonsumsi maka LDL akan banyak tersimpan dalam tubuh (Hartanto, 2004).

Penimbunann lemak tubuh dipengaruh banyak faktor selain penggunaan hormon estrogen dan 
progesteron, penimbunan lemak tubuh dipengaruhi oleh konsumsi makanan, aktifitas, stress, usia, dan penyakit degeneratif. Berdasarkan wawancara singkat dengan akseptor sebagian besar mengatakan bahwa setelah penggunaan kontrasepsi nafsu makan akseptor cenderung meningkat selain itu beberapa akseptor seroing mengkonsumsi makanan berminyak dan berlemak. Akseptor di PMB Dwi Astutik sebagian besar tidak bekerja sehingga aktivitas yang paling banyak dikerjakan adalah aktivitas rumah tangga dan merawat anak.

Menurut Hartanto (2004) berat badan meningkat bervariasi, pada umumnya selama satu tahun pemakaian meningkat sebanyak 1-5 kg. Peningkatan berat badan akibat kontrasepsi pil kombinasi dan suntik DMPA dikatakan beresiko apabila IMT berada pada interval obesitas. Pada wanita obesitas penggunaan suntik DMPA akan meningkatkan resiko mengalami penyakit degenratif seperti anterosklerosis, jantung koroner, hipertensi, diabetes melitius dan stroke (Sri, 2008).

Dilihat dari crosstab perebedaan pengaruh lama pemakaian kontrasepsi pil kombinasi dengan suntik DMPA menunjukkan bahwa presentase akdeptor yang menggunakan kontrasepsi pil kombinasi dan suntik DMPA setelah 12 bulan pemakaian sebagian besar mengalami peningkatan IMT. Hal ini didukung oleh pernyataan akseptor yang menyatakan bahwa nafsu makannya meningkatdan merasa berat badannya ikut bertambah. Sesuai dengan teori bahwa kandungan hormon dalam kontrasepsi pil kombinsasi terutama hormon esrogen mampu memodulasi nafsu makan dan meningkatkan deposisi lemak, sedangkan kandungan progesteron saja dalam suntik DMPA merangsang pusat pengendali nafsu makan yang ada dihipotalamus menyebabkan akseptor makan lebih banyak dari pada biasanya.

Hasil penelitian ini didukung oleh penelitian Andriyati, dkk (2014), yang menyatakan bahwa pada penggunaan kontrasepsi pil kombinasi sebagian besar penggunanya mengalami perubahan berat badan yang dikarenakan adanya retensi cairan dari progestin dan estrogen yang mengakibatkan bertambahnya lemak subkutan terutama pada pinggul, paha dan payudara. Dimana hasil uji statistik yang didapatkannya yaitu nilai $\mathrm{p}<0,05$.

Setyarini (2015) menyatakan dalam penelitiannya hubungan lama penggunaan DMPA dengan kadar lemak menunjukkan semakin lama penggunaan DMPA semakin besar presentase akseptor yang memiliki kadar lemak dalam interval 30-35\% dan $>35 \%$ dalam kategori mendekati tinggi dan tinggi, sementara pada presentase IMT akseptor menunjukkan dalam interval 25,0- 
29,9 dan >30 yang termasuk kastegori overweight dan obesitas.

Berdasarkan hasil observasi dan wawancara akseptor yang didapatkan peneliti pada responden akseptor pil kombinasi di PMB Dwi Astutik pada 12 bulan pertama pemakaian sebagian besar mengalami peningkatan IMT sedangkan pada pemakaian $>12$ bulan berat badan cenderung tetap dan hanya sebagian kecil yang mengalami peningkatan IMT, selama pemakaian kontrasepsi pil kombinasi sebagian besar responden melakukan pekerjaan rumah tangga dan pekerjaan lainnya seperti biasa, pola makan selama pemakaian sebagian ada yang mengalami peningkatan dan sebagian lagi tidak, ratarata responden lebih banyak mengkonsumsi cemilan berupa gorengan dan makanan berlemak. Sementara itu, hasil observasi dan wawancara responden akseptor suntik DMPA pada 12 bulan pertama pemakaian dan >12 bulan mengalami peningkatan IMT dan sebagian kecil tidak mengalami peningkatan.

Berdasarkan hasil penelitian diatas dapat disimpulkan bahwa kadnungan hormon yang terdapat pada kontrasepsi hormonal berupa pil kontrasepsi dan suntik DMPA memiliki efek samping meningkatan berat badan yang dapat mempengaruhi besar nilai IMT seseorang, dalam penggunaanya berdasarkan hasil statistik kontrasepsi pil kombiinasi lebih besar pengaruhnya dalam meningkatkan IMT $(0,001)$. Selain itu pola kebiasaan sehari-hari juga ikut berpengaruh seperti pola makan, pola aktifitas, dan pola istirahat.

\section{PENUTUP}

Hasil penelitian ini menunjukkan terdapat perbedaan pengaruh lama pemakaian kontrasepsi pil kombinasi dengan suntik DMPA terhadap peningkatan indeks massa tubuh di PMB Dwi Astutik A.Md. Keb, yang ditunjukkan dengan hasil analisa chi-square menggunakan fisher exact test yaitu nilai $\rho$ value $0,048>0,001$. Sehingga semakin lama penggunaan kontrasepsi pil kombinasi lebih erat hubungannya dengan peningkatan indeks massa tubuh dibandingkan dengan suntik DMPA.

Saran bagi profesi yaitu Penelitian ini dapat digunakan sebagai bahan edukasi untuk profesi atau tenaga kesehatan lainnya dalam memberikan kontrasepsi hormonal pada akseptor. Dengan mengetahui indeks massa tubuh akseptor, bidan dapat memperhitungkan apakah penggunaan kontrasepsi hormonal pil kombinasi maupun suntik DMPA dapat diberikan secara rasional atau tidak, untuk menghindari angka kejadian obesitas pada akseptor KB hormonal. 


\section{DAFTAR PUSTAKA}

Affandi, Biran. 2011. Buku Panduan Praktis Pelayanan Kontrasepsi. Jakarta: PT. Bina Pustaka Sarwono Prawirohardjo

Almatsier, S. 2010. Penuntun Diet. Cetakan ke 25. Jakarta: PT Gramedia Pustaka Utama.

Andriyati, Dewi, Rusli, Khairani, Mauljadi, Henry, dan Johny Marpaung. 2014. Perbandingan Berat Badan pada Akseptor Kontrasepsi Hormonal Oral Kombinasi Sebelum, Sesudah 6 Bulan dan 12 Bulan Penggunaan. Majalah Kedokteran Nusantara. Vol. 47, No. 3. Program Studi Megister Kedokteran Klinik. Departemen Obstetri dan Ginekologi, Fakultas Kedokteran Universitas Sumatera Utara.

BKKBN. 2010. Kontrasepsi. http://bkkbn.go.id/ diakses pada tanggal 13 November 2018.

Dinas Kesehatan Provinsi Jawa Timur. 2017. Profil Kesehatan Provinsi Jawa Timur 2016. Surabaya: Dinkes Prov. Jatim.

Dinas Kominfo Kabupaten Malang. 2016. Statistik Pembangunan Daerah Kabupaten Malang Tahun 2016. Edddisi 2017. Malang: Dinas Kominfo Kab. Malang.

Hartanto, Hanafi. 2004. Keluarga Berencana dan Kontrasepsi. Jakarta: Pustaka Sinar Harapan.

Kemenkes RI. 2013. Buku Saku Pelayanan kesehatan Ibu di Fasilitas Kesehatan Dasar dan Rujukan, Edisi 1. Kementerian Kesehatan Republik Indonesia. Jakarta, hal. 245-247. 2013. Buletin Jendela Data dan Informasi Kesehatan. Semester II, ISSN 2088 - 270X. Jendela Datinkes: Jakarta.

2018. Data dan Informasi Profil Kesehatan Indonesia 2017. Kemenkes RI: Jakarta.
Prawirohardjo, Sarwono. 1999. Ilmu Kebidanan, Ed. 3. Jakarta: PT Bina Pustaka Sarwono Prawirohardjo. . 2011. Ilmu Kandungan, Ed. 3. Jakarta: PT Bina Pustaka Sarwono Prawirohardjo.

Rufaridah, Anne, Kurnia Putri, Ayuro Cumayunaro, dan Sidaria. 2017. Perbedaan Indeks Massa Tubuh pada Akseptor KB Suntik 1 dan 3 Bulan. Jurnal Endurance. Hal. 270-279. STIKES Ranah Minang, Sumatera Barat, Indonesia.

Saepudin, M. 2011. Metodologi Penelitian Kesehatan Masyarakat. Jakarta : CV Trans Info Media.

Saifuddin, Abdul Bari. 2006. Buku Ilmu Kebidanan Sarwono Prawirohardjo. Jakarta: Yayasan Bina Pustaka Sarwono Prawirohardjo.

Samosir, N. 2013. Hubungan Kelebihan Berat Badan dengan Kadar Gula Darah. Diakses dari www.repository.usu.ac.id pada tanggal 13 November 2018.

Setiawati, A. 2013. Pengaruh Kontrasepsi Suntik DMPA Terhadap Peningkatan Berat Badan Akseptor KB di Desa Kedawung Kecamatan Nglegok Kabupaten Blitar. Skripsi. Program Studi S1 Kebidanan Fakultas Kedokteran Universitas Brawijaya.

Setyarini, Didien Ika. 2015. Lama Penggunaan Depo Medroksi Progesterone Asetat (DMPA) dan Indeks Massa Tubuh (IMT) Akseptor Kontrasepsi Suntik. Jurnal Informasi Kesehatan Indonesia. Vol. 1 No. 1. Polteknik Kesehatan Kemenkes Malang.

Sulistyawati, Ari. 2013. Pelayanan Keluarga Berencana. Jakarta: Salemba Medika.

Supariasa, I Dewa Nyoman, Bachyar Bakri, dan Ibnu Fajar. 2002. Penilaian Status Gizi. Jakarta: EGC.

Suratun, S Maryani, T Hartini, Rusmiati, dan Saroha 2008. Pelayanan Keluarga Berencana dan Pelayanan Kontrasepsi. Jakarta: Trans Info Media. 